initial values or the lack of any significant change when spironolactone was given. Measurements of rectal potential difference also failed to show any difference between the groups. Thus the sodium transport system of the colon seemed to be unstimulated in the patients responding to spironolactone, to react normally to an exogenous mineralocorticoid stimulus (9- $\alpha$-fluorocortisol), and to reduce normally when spironolactone was given.

There are several possible explanations for our failure to find any evidence of biological effects of mineralocorticoidism in the responding group. Firstly, their hypertension may not have been due to mineralocorticoid excess, the action of spironolactone being through a mechanism other than mineralocorticoid antagonism. Secondly, the mineralocorticoids being produced may have lacked actions on sodium and potassium metabolism that we customarily expect. Thirdly, as suggested by Grim, ${ }^{8}$ although the serum aldosterone levels were in the normal range, they were possibly inappropriately high for the renin levels. Both of these latter suggestions are speculative and the most likely explanation is that mineralocorticoids are rarely responsible for the increase in blood pressure in patients with essential hypertension.

Our results do not, unfortunately, cast any certain light on the mode of action of spironolactone in essential hypertension since all the changes that we observed were common to all groups and occurred to similar degrees. The reduction of body fluid and body sodium may be the significant factor but, if so, these changes appear to lower blood pressure only in some patients.

We gratefully acknowledge the expert technical help given by Miss
Jennifer Mackenzie and to G D Searle and Co Ltd, for generously supplying spironolactone.

\section{References}

1 Brown, J J, et al, British Medical fournal, 1972, 1, 729.

2 Winer, B M, Lubbe, W F, and Colton, T, fournal of the American Medical Association, 1968, 204, 117.

3 Wolf, R I, et al, fournal of the American Medical Association, 1966, 198, 1143.

4 Adlin, E V, Biddle, C M, and Channick, B J, American fournal of Medical Science, 1971, 261, 67 .

5 Carey, R M, et al, Archives of Internal Medicine, 1972, 130, 849.

6 Spark, R F, and Melby, J C, Annals of Internal Medicine, 1971, 75, 831. Liddle, G W, Carey, R M, and Douglas, J G, Southern Medical fournal, 1973, 66, 51.

${ }^{8}$ Grim, E, Archives of Internal Medicine, 1975, 135, 347.

${ }^{9}$ Edmonds, C J, and Godfrey, R C, Gut, 1970, 11, 330.

${ }_{10}$ Edmonds, C J, and Richards, P, Lancet, 1970, 2, 624.

11 Beevers, D G, et al, Gut, 1975, 16, 36.

12 Efstratopoulos, A D, Peart, W S, and Wilson, G A, Clinical Science and Molecular Medicine, 1974, 46, 489.

13 Tomkins, A M, and Edmonds, C J, Gut, 1975, 16, 277.

14 Barnaby, C F, and Jasani, B M, Physics in Medicine and Biology, 1968, 13, 561.

15 Jasani, B M, and Edmonds, C J, Metabolism, 1971, 20, 1099.

16 Edmonds, C J, Jasani, B M, and Smith, T, Clinical Science and Molecular Medicine, 1975, 48, 431.

17 Archampong, E Q, and Edmonds, C J, Gut, 1972, 13, 559.

18 Crane, M G, Harris, J J, and Johns, V J, American fournal of Medicine, 1972, 52, 457.

19 Dunn, M J, and Tannen, R L, Kidney International, 1974, 5, 317.

${ }^{20}$ Lebel, M, et al, Lancet, 1974, 2, 308.

21 Padfield, P L, et al, Lancet, 1975, 1, 548.

\title{
Comparative double-blind study of cephalexin and co-trimoxazole in urinary tract infections
}

\author{
P E GOWER, P R W TASKER
}

British Medical fournal, 1976, 1, 684-686

\section{Summary}

Treatment with cephalexin $1 \mathrm{~g}$ twice daily and cotrimoxazole 2 tablets twice daily was compared in a double-blind, randomised study of 100 women with urinary tract infections. Co-trimoxazole gave a significantly higher cure rate compared with cephalexin two and six weeks after the one-week course of treatment. The higher failure rate with cephalexin was not related to the age of the patient, presentation, pyelographic appearances, or type of organism in the initial infection. Among the failures all but one of the organisms were sensitive to cephalexin. With the dosage regimen and duration of treatment used in this study cotrimoxazole appears to be superior to cephalexin in the management of acute urinary infections.

\section{Introduction}

Both cephalexin and co-trimoxazole have been used successfully to treat urinary tract infections. In a double-blind trial cephal-

Charing Cross Hospital, London W6 8RF

P E GOWER, MD, MRCP, consultant nephrologist

P R W TASKER, MB, BS, senior house officer, department of medicine exin and ampicillin were found to be equally effective, though cephalexin was better tolerated. ${ }^{1}$ Brumfitt and Pursell ${ }^{2}$ compared ampicillin, cephalexin, co-trimoxazole, and trimethoprim in 300 patients from three separate populations with urinary infections. The cure rate was slightly, though not significantly, higher with co-trimoxazole than with either ampicillin or cephalexin. Cure was defined at a six-week follow-up examination, and no details of the pyelograms were given.

We report a double-blind, controlled comparison of cephalexin and co-trimoxazole in a group of women with urinary infections who were fully investigated. Most were treated as outpatients.

\section{Patients and methods}

A total of 100 women with symptomatic or asymptomatic urinary tract infections were selected for study; 24 were attending a urinary infection clinic, and 76 presented in the casualty department with acute urinary symptoms. No patient had a catheter-induced infection. The diagnosis was confirmed by suprapubic aspiration of the bladder. All patients had either a blood urea or plasma creatinine estimation and an intravenous pyelogram. None were pregnant.

Tablets containing either cephalexin $(500 \mathrm{mg})$ or co-trimoxazole ( $80 \mathrm{mg}$ trimethoprim, $400 \mathrm{mg}$ sulphamethoxazole) but identical in appearance were prescribed in one-week courses of two tablets twice a day. The courses were allocated at random to successive patients in whom infection was confirmed. The patients were asked to return to the clinic to give midstream urine samples $(a)$ during treatment, (b) two weeks after completing treatment, and (c) six weeks after completing treatment. A further suprapubic aspiration of urine was undertaken if the midstream urine samples contained 
either a pure growth of a recognised urinary tract pathogen or a mixed growth in which such organisms predominated. ${ }^{3}$

Quantitative urine cultures were performed by the filter-paper-strip technique. ${ }^{4}$ The sensitivities of the organisms to antimicrobial agents were determined by the disc-diffusion method without pre-diffusion using $30 \mu \mathrm{g}$ cephalexin and $25 \mu \mathrm{g}$ of a trimethoprim-sulphamethoxazole mixture. In patients whose infections recurred, strains of Escherichia coli were typed with antisera specific for $\mathrm{O} 1, \mathrm{O} 2, \mathrm{O} 4, \mathrm{O}$, O7, O9, O11, O18, O39, and $\mathrm{O} 75$.

\section{Results}

Altogether 93 patients completed treatment and were seen two weeks later. Of these, 47 received cephalexin and 46 co-trimoxazole. Three patients given cephalexin and four given co-trimoxazole did not return for follow-up. Six patients given cephalexin and seven given co-trimoxazole who were seen two weeks after treatment failed to attend six weeks after treatment.

Age of patients-The mean age of the 47 patients given cephalexin was 30 (range 19-67) years, and that of the 46 patients given cotrimoxazole 32 (range 19-72) years. Only three patients were aged 60 or more, two in the cephalexin group and one in the cotrimoxazole group.

Chief presenting features-Seventy-five of the patients (80\%) presented with acute urinary symptoms (dysuria or frequency, with or without loin pain), 11 were asymptomatic, and seven had acute pyelonephritis (loin pain and tenderness, fever over $38^{\circ} \mathrm{C}$ ). The distribution of the presenting features in the two treatment groups was similar.

Renal function - In all cases the blood urea was under $6.6 \mathrm{mmol} / \mathrm{l}$ $(40 \mathrm{mg} / 100 \mathrm{ml})$ and the plasma creatinine under $115 \mu \mathrm{mol} / 1(1.3 \mathrm{mg} /$ $100 \mathrm{ml})$.

Pyelographic appearances-Normal pyelograms were obtained from $37(79 \%)$ of the patients given cephalexin and from $29(63 \%)$ of those given co-trimoxazole. Of the 10 patients in the cephalexin group with abnormal pyelograms three had chronic pyelonephritis, three caliceal cysts, one obstructive atrophy, and two a duplex kidney; one had had a nephrectomy. None had calculi. Of the 17 patients in the co-trimoxazole group with abnormal pyelograms, seven had chronic pyelonephritis, four stones, one papillary necrosis, two obstructive atrophy, and three duplex kidney. None had caliceal cysts.

\section{ORGANISMS ISOLATED FROM INITIAL SUPRAPUBIC ASPIRATE}

$E$ coli predominated in both groups of patients, most of the remaining infections being due to either Proteus mirabilis or micrococci. The distribution of the bacteria causing the infections was similar in the two groups (table I).

TABLE I-Organisms isolated from initial sample of urine taken by suprapubic aspiration

\begin{tabular}{l|c|c} 
& $\begin{array}{c}\text { Cephalexin group } \\
(\mathbf{n}=\mathbf{4 7})\end{array}$ & $\begin{array}{c}\text { Co-trimoxazole group } \\
(\mathbf{n}=46)\end{array}$ \\
\hline $\begin{array}{l}\text { Escherichia coli } \\
\text { Proteus mirabilis }\end{array}$ & 31 & 35 \\
Klebsiella sp & 7 & $7^{*}$ \\
Micrococci & 5 & 1 \\
Streptococcus faecalis & 1 & $4^{*}$ \\
Streptococcus viridans & 1 & \\
Pseudomonas aeruginosa & 1 & \\
\hline
\end{tabular}

*One patient had a mixed growth.

TABLE $\mathrm{II}-$ Recurrence rates two and six weeks after treatment

\begin{tabular}{l|c|c|c|c|c}
\hline & Cephalexin group & Co-trimoxazole group & \\
\cline { 1 - 4 } & $\begin{array}{c}\text { No } \\
\text { with } \\
\text { recurrence }\end{array}$ & $\begin{array}{c}\text { attending } \\
\text { for } \\
\text { follow-up }\end{array}$ & $\begin{array}{c}\text { No } \\
\text { with } \\
\text { recurrence }\end{array}$ & $\begin{array}{c}\text { No } \\
\text { attending } \\
\text { for } \\
\text { follow-up }\end{array}$ & P \\
\hline $\begin{array}{l}\text { Recurrence at two } \\
\text { weeks }\end{array}$ & 15 & 47 & 2 & 46 & $<0.005$ \\
$\begin{array}{l}\text { Cumulative recurrence } \\
\text { at six weeks }\end{array}$ & 17 & 41 & 6 & 39 & $<0.02$ \\
\hline
\end{tabular}

EFFECTS OF TREATMENT AFTER TWO AND SIX WEEKS

During treatment all midstream urine specimens were sterile. Two weeks after treatment, however, $15(32 \%)$ of the 47 patients given cephalexin and $2(4 \%)$ of those given co-trimoxazole had a recurrence $\left(\chi^{2}=10.05 ; P<0.005\right)$. At six weeks two further patients given cephalexin and four given co-trimoxazole had a recurrence, giving cumulative failure rates of $41 \%$ and $15 \%$ respectively $\left(\chi^{2}=5.89 ; P<0.02\right)$ (table II).

\section{HOST FACTORS IN PATIENTS WHOSE INFECTIONS RECURRED}

In each treatment group the mean ages of the patients whose infections recurred at two and six weeks were similar to that of the patients whose infections did not recur.

Of the 37 patients with normal pyelograms given cephalexin 12 had a recurrence of the infection at two weeks. Of the 29 patients with normal pyelograms given co-trimoxazole only one had a recurrence at two weeks. This difference is highly significant $\left(\chi^{2}=6.899\right.$; $P<0.01)$. A similar trend was observed for patients with abnormal pyelograms. Of the 10 patients given cephalexin three had a recurrence, and of the 17 given co-trimoxazole one had a recurrence. The difference in recurrence rates between the cephalexin and cotrimoxazole treated patients with abnormal pyelograms did not, however, reach statistical significance at the $5 \%$ level.

\section{ORGANISMS FOUND AT RECURRENCE}

Of the 17 infections that recurred after cephalexin 10 appeared to be due to the same organism or serotype ("relapse"), and six appeared to be due to different organisms or serotypes ("reinfection"); one organism was resistant to cephalexin both before and after treatment. Of the six infections that recurred after co-trimoxazole five appeared to be due to the same organism or serotype and one to a different serotype. All but one of the organisms from patients whose infections recurred were sensitive to discs containing either cephalexin $30 \mu \mathrm{g}$ or cotrimoxazole $25 \mu \mathrm{g}$.

\section{SIDE EFFECTS}

Side effects were remarkably few. Three patients given cotrimoxazole complained of a rash, and one given cephalexin developed a vaginal discharge due to candida. In none of these patients was treatment stopped.

\section{Discussion}

These results show that with the treatment schedule used co-trimoxazole is superior to cephalexin in the management of acute urinary infections. The cure rate of $68 \%$ two weeks after treatment with cephalexin compares favourably with other reports $(50-90 \%) .^{125-8}$ Comparison between these series is difficult, however, owing to differences in the types of cases treated and in the dose regimens and definitions of "cure" used. Our cure rate two weeks after co-trimoxazole (96\%) was superior to many other reported series 10 days to three weeks after treatment $(55-92 \%){ }^{9-16}$

The reasons for the relatively high failure rate with cephalexin are not readily apparent. With one exception all the organisms were sensitive to discs containing $30 \mu \mathrm{g}$ cephalexin. All the patients with recurrences had sterile urine during treatment. No patient stopped taking the drug because of side effects, which was considered by Leigh $e t a l^{17}$ to be the principal cause of failure in their series of patients treated with cephalexin. All the patients had normal renal function, and high urinary levels of cephalexin are likely to have been achieved.

Cephalexin is rapidly cleared from the blood and has a half life of 60 minutes. ${ }^{18} \mathrm{~A}$ dose of $1 \mathrm{~g}$ twice daily may have given only transient high urinary levels, and possibly residual organisms persisted in the stationary phase and multiplied when the level of antibiotic was low or absent. In volunteers urine concentrations of about $10 \mathrm{mg} / 100 \mathrm{ml}$ have been found between 
six and 12 hours after a $1-\mathrm{g}$ dose. ${ }^{19}$ Brumfitt and Pursell ${ }^{2}$ tound that a dose of cephalexin given twice daily was as efficient as a more conventional dose given three or four times a day. Cotrimoxazole has a half life of 10 hours, ${ }^{20}$ and a more constant urinary level would be found throughout treatment.

Cephalexin readily induces spheroplast formation in Gramnegative organisms, which may persist in a hypo-osmotic or iso-osmotic environment. This may be an important cause for a persistent infection (relapse) in a patient treated with cephalexin. We did not look for bacterial variants. Co-trimoxazole is less likely to induce spheroplast formation.

The reinfection rate two weeks after cephalexin was high, representing $40 \%$ of all recurrences. Other workers using cephalexin have also found a relatively high reinfection rate when expressed as a percentage of the overall recurrence rate. ${ }^{1}{ }^{8} 8_{21}$ Comparable figures for reinfection after cotrimoxazole are difficult to obtain from other series. Stamey and Condy ${ }^{22}$ suggested that the reinfection rate after a trimethoprimsulphamethoxazole mixture is low due to the secretion of trimethoprim into the vaginal fluid and eradication of periurethral organisms. Thus co-trimoxazole may have an advantage over cephalexin in reducing both relapses and reinfections.

In the past much emphasis has been placed on the distinction between "relapse" with the same organism (implying treatment failure) and "reinfection" with a different organism or serotype (implying successful treatment). There are several fundamental objections to these claims, which are discussed elsewhere. ${ }^{23}$ In summary, (a) reinfection due to the same organism is impossible to distinguish from a relapse, $(b)$ some organisms are autoagglutinable, and (c) serotyping of 10 colonies obtained from suprapubic aspirates has shown that mixed growths containing more than one serotype occur in at least $2 \%$ of infections. ${ }^{23}$ Such organisms may have different antibiotic sensitivities and be preferentially selected with treatment. These objections make the distinction between relapse and reinfection difficult, and in any study it is conceivable that all the relapses were reinfections with the same organism, or even that the reinfections were relapses with organisms unrecognised in the initial suprapubic aspirate.

We thank Miss R Phillips for technical help. The cephalexin tablets were supplied by Glaxo Laboratories Ltd, and the co-trimoxazole by Burroughs Wellcome \& Co. The identical appearance of the tablets was achieved through co-operation between both manufacturers, for which we are grateful.

\section{References}

${ }_{1}^{1}$ Davies, J A, et al, British Medical fournal, 1971, 3, 215.

2 Brumfitt, W, and Pursell, R, British Medical fournal, 1972, 2, 673.

3 Gower, P E, and Roberts, A P, Clinical Nephrology, 1975, 3, 10.

4 Leigh, D A, and Williams, J D, fournal of Clinical Pathology, 1964, 17, 498.

${ }^{5}$ Mohring, K, Genster, H G, and Madsen, P O, fournal of Urology, 1971, 106, 757.

${ }^{6}$ Montgomery, W G, and Cox, C E, International fournal of Clinical Pharmacology, 1971, 4, 212.

${ }^{7}$ Seneca, H, Uson, A, and Peer, P, fournal of Urology, 1972, 107, 832.

${ }^{8}$ Ries, K M, et al, Antimicrobial Agents and Chemotherapy. 1973, 4, 593.

${ }^{9}$ Gruneberg, R N, and Kolbe, R, British Medical fournal, 1969, 1, 545.

10 Reeves, D S, et al., British Medical fournal, 1969, 1, 541.

11 Wren, B G, Medical fournal of Australia, 1972, 1, 261.

12 Crichton, E P, and McDonnell, C E, Canadian Medical Association fournal, 1972, 107, 292.

13 Gleckman, R A, Fournal of Infectious Diseases, 1973, 128, suppl, p 647.

${ }^{14}$ Harding, G K M, and Ronald, A R, Fournal of Infectious Diseases, 1973, 128, suppl, p 641 .

${ }^{15}$ Knudsen, J B, et al., Scandinavian Fournal of Infectious Diseases, 1973, 5, 55.

${ }^{16}$ Cosgrove, M D, and Morrow, J W, fournal of Urology, 1974, 111, 670.

17 Leigh, D A, Faiers, M C, and Brumfitt, W, Postgraduate Medical fournal, 1970, 46, suppl, p 69.

18 Gower, P E, and Dash, C H, British fournal of Pharmacology, 1969, 37, 738.

19 Dash, C H, personal communication.

${ }^{20}$ Schwartz, D E, and Ziegler, W H, Postgraduate Medical fournal, 1969, 45, suppl, p 32.

21 Wise, H A, and Schwartz, H, fournal of Urology, 1971, 105, 440.

${ }^{22}$ Stamey, T A, and Condy, W, fournal of Infectious Diseases, 1975, 131, 261.

${ }^{23}$ Roberts, A P, Gower, P E, and Koutsaimanis, K G, in Proceedings of VI International Congress of Nephrology (Florence), 1975. In press.

\title{
Recurrent haematuria: role of renal biopsy and investigative morbidity
}

\author{
J MICHAEL， N F JONES， D R DAVIES, J R TIGHE
}

British Medical fournal, 1976, 1, 686-688

\section{Summary}

The usefulness of renal biopsy in investigating unexplained haematuria was assessed by a study of 33 adults referred consecutively with this syndrome. Unequivocal abnormalities were seen on light microscopy or immunofluorescence in 31 of the 33 specimens of renal tissue examined. In 18 patients deposits of $\operatorname{IgA}$ were present in the mesangium.

Loin pain occurred in only two of the 18 patients with mesangial IgA deposits, compared with 11 of the 15

St Thomas's Hospital and Medical School, London SE1 7EH J MICHAEL, MB, MRCP, medical registrar

N F JONES, MD, FRCP, consultant physician

D R DAVIES, MB, MRCPATH, senior lecturer in morbid anatomy

J R TIGHE, MD, FRCPATH, professor of histopathology patients without these deposits. Seven of the nine women in this series had had loin pain compared with only six of the 24 men. Thus a woman with loin pain and haematuria was not likely to have mesangial IgA nephropathy but this was found in 14 of the 18 men with unexplained painless haematuria.

Failure to appreciate the role of renal biospy in the investigation of unexplained haematuria may result in unnecessary radiology, considerable morbidity, and even in unjustified nephrectomy.

\section{Introduction}

When haematuria occurs the cause is usually disclosed by urine culture, radiological visualisation of the urinary tracts, and cystoscopy. The results of these investigations, however, are normal in patients with some forms of glomerulonephritis that also may present as recurrent or persistant haematuria. The diagnosis then can be made only by renal biopsy. The value of renal biopsy in this condition has been questioned ${ }^{12}$ and its use 